\title{
BMJ Open Are there social gradients in the occurrence of lung cancer and in the survival of lung cancer patients? Findings from an observational study using German claims data of Lower Saxony
}

Sebastian Schröder, ${ }^{1}$ Johannes Beller (1) , ${ }^{1}$ Heiko Golpon, ${ }^{2}$ Siegfried Geyer ${ }^{1}$

To cite: Schröder S, Beller J, Golpon $\mathrm{H}$, et al. Are there social gradients in the occurrence of lung cancer and in the survival of lung cancer patients? Findings from an observational study using German claims data of Lower Saxony. BMJ Open 2020;10:e036506. doi:10.1136/ bmjopen-2019-036506

- Prepublication history for this paper is available online. To view these files, please visit the journal online (http://dx.doi. org/10.1136/bmjopen-2019036506).

Received 18 December 2019

Revised 24 July 2020

Accepted 28 July 2020
Check for updates

(C) Author(s) (or their employer(s)) 2020. Re-use permitted under CC BY-NC. No commercial re-use. See rights and permissions. Published by BMJ.

${ }^{1}$ Medical Sociology, Hannover Medical School, Hannover,

Germany

${ }^{2}$ Pneumology, Hannover Medical School, Hannover, Germany

Correspondence to Johannes Beller; beller.johannes@mh-hannover. de

\section{ABSTRACT}

Objectives Only a few studies on health inequalities in terms of lung cancer are available. We examined whether social inequalities are present for the occurrence of lung cancer. Confining the analyses to patients, it was also examined whether survival over the observation period and over a standardised period of 18 months differed by occupational position and income.

Methods Our findings are based on claims data from a German statutory health insurance covering 2005-2016. The database comprised $\mathrm{N}=3163211$ women $(50.7 \%)$ and men (49.3\%) aged 18 years and older. Diagnoses (International Statistical Classification of Diseases and Related Health Problems 10th Revision: C34.0 to C34.9) were hospital-based, and income and occupational position were used as indicators of socioeconomic position. Analyses on social gradients were performed for employed and retired insured, but only for employed insured information on occupation and on income were available, for retired women and men only income was available. Analyses were performed by means of proportional hazard regression.

Results In employed women, social gradients for the occurrence emerged for occupational position, but not for income. In men, social differences were found for both indicators. For retired insured, income gradients were found in men. Looking at overall survival, neither in women nor in men social gradients emerged.

Conclusions The reported social inequalities in the occurrence of lung cancer are pointing towards social differences in smoking behaviour, exposition to hazardous occupation-related substances and differences in preventive strategies. The absence of social inequalities in survival after lung cancer suggests equality in medical treatment of the disease.

\section{BACKGROUND}

Lung cancer is one of the most frequent malignant diseases in Germany. According to national statistics for 2014, age-standardised rates were $57.3 / 100000$ in men and
Strengths and limitations of this study

- A large population-based sample was used

- Different indicators of social inequality at different points in the illness process were used to study inequality, including inequality in the occurrence of lung cancer and the survival of patients with lung cancer.

- Sensitivity analyses indicated the robustness of the current results.

- The sample was geographically limited to the area of Lower Saxony, Germany.

- Information about psychosocial and behavioural factors to explain inequalities in lung cancer could not be obtained, which needs to be analysed in future studies.

29.0/100000 in women. ${ }^{1}$ In 2013/2014, it had the largest share of cancer-related deaths in men $(25 \%)$ and the second most frequent one in women $(15 \%)$. In spite of decreasing rates of smokers and due to demographic change, lung cancer will also make a substantive contribution to population morbidity in the years to come. ${ }^{2}$ Social inequalities were also reported for lung cancer. ${ }^{3}$ However, compared with studies on subjective health or other frequently occurring diseases like cardiovascular conditions, only limited empirical evidence exists regarding social inequalities in lung cancer. Analysing inequalities in lung cancer requires differentiation between incidence/prevalence and death.

Studying social inequalities in lung cancer is a meaningful endeavour. With respect to the disease course and outcomes, difference by socioeconomic status (SES) refers to different types of behaviours and expositions that can be changed in particular to 
smoking, ${ }^{4}$ to the differential success of preventive poli$\operatorname{cies}^{5}$ and to occupation-related expositions to potentially hazardous environmental conditions and carcinogenic substances such as asbestos or polycyclic hydrocarbons. ${ }^{6-8}$ If social inequalities in patients are considered, that is, with respect to the disease course and outcomes, analyses are rather not pointing towards differences in behaviour. In this case, stage at diagnosis and differing qualities of medical care may be responsible for variations of disease outcomes. This had been demonstrated, for example, for the USA, where the membership in different types of health insurances was associated with the risk of death after lung cancer, and the types of insurances were again associated with different socioeconomic positions. ${ }^{9}$

Research on social inequalities in lung cancer incidence is rare, and this applies to Germany as well as to the international literature. Nationwide cancer registration was implemented in 2006, but registers do not contain sociodemographic information. Thus, only a few publications are available. In an individual-level study, social inequalities in the incidence of lung cancer were reported, but the situation was less clear for case fatalities. ${ }^{10}$ Three more incidence studies were published, but they used area-based measures for classifying women and men according to socioeconomic position. ${ }^{11-13}$ In international publications, social inequalities in terms of lung cancer incidence were also reported for income, education and occupational position ${ }^{14}$; a recent study was based on pooled samples from different countries, but the numbers of lung cancer cases did not permit to differentiate between countries. ${ }^{15}$ Social inequalities for lung cancer incidence were also reported for Danish males, ${ }^{16}$ and in a Canadian ecological study, associations between area-based income levels and lung cancer were found. ${ }^{17}$ The situation is less straightforward for the survival of lung cancer. For Germany, an older study reported social differences in terms of income, but not for education. ${ }^{10}$ At the international level, survival differences were reported in terms of income ${ }^{18}$ or education, ${ }^{14}$ while in a Dutch study, no social gradients were reported for occupation. ${ }^{19}$ Social gradients as depicted by area-based measures were also examined for survival, and lower survival rates were reported for patients from areas classified as socially deprived. ${ }^{20}$ Taken together, the findings of these studies are heterogeneous and may depend on the structure of the healthcare system. ${ }^{9} 2122$

Against the backdrop of the findings reported above, the current situation of health inequalities in terms of incidence of lung cancer and survival of patients with lung cancer in Germany is unclear. As registry data are unsuitable for inequality analyses, we used claims data derived from a large German statutory health insurance covering the time period 2005-2016. This made it possible to perform analyses by considering income and occupation as indicators of socioeconomic position and for different groups of insured on the basis of large case numbers. Differentiating between these two is necessary because for retired insured only one SES indicator (income) was available.

The size of the insurance data made it possible to perform analyses along three lines:

- It was examined whether lung cancer differed by income and occupation by performing separate analyses for women and for men. Further differentiations had to be carried out for economically active and for retired individuals. Only for the first-mentioned group data on occupational position and income were available, while for pensioners, only income was recorded. Besides the availability of SES indicators, the differentiation between economically active individuals and pensioners is appropriate because social gradients are narrowing with age, that is, after transition into retirement. ${ }^{23}$

- It was examined whether case fatalities (mortality) of patients with lung cancer were differing by income and occupation. In these analyses, only patients with lung cancer were considered.

- Mortality was considered for the whole study period by adjusting the length of follow-up. A different line of analysis was performed for survival of 18 months after clinical diagnosis. According to the data of 2013/2014 published by the Robert Koch Institute, approximately $60 \%$ of patients will have died within 18 months after diagnosis. It was assumed that this observation period would permit to differentiate by SES with sufficient precision. ${ }^{1}$

Thus, given the missing evidence about social inequalities in lung cancer in Germany, the current study aims to examine the extent of social inequalities in incidence and mortality of lung cancer in Germany.

\section{METHODS}

The following analyses are based on claims data of all insured persons from the Local Statutory Health Insurance of Lower Saxony (Allgemeine Ortskrankenkasse Niedersachsen, AOKN). The data used in the current study do not represent a sample of this health insurance population, but consist of the entire population of insured persons of the Local Statutory Health Insurance of Lower Saxony, covering the years 2005-2016 for individuals aged at least 18 years. ${ }^{24}$ The insurance population included in the analyses consisted of 3163211 cases of men $(49.3 \%)$ and women $(50.7 \%)$. The membership in the insurance may vary, thus the dataset is left and right censorised.

In Germany, health insurance coverage is compulsory for all residents, ${ }^{25}$ and below a certain income threshold insurance with the statutory system is obligatory. Statutory health insurances are operating under public law, and all are covering the same healthcare programme as defined by a national board ('Gemeinsamer Bundesausschuss'). In 2011, $86 \%$ of all employed women and men were covered by the statutory system, family members are insured free of charge, and in 2015 , only $0.1 \%$ were 
uninsured. Insured are divided into different groups; for the following analyses, this applies to employed, family insured, unemployed, pensioners and an undefined group.

Diagnoses were all hospital-based and coded according to the International Statistical Classification of Diseases and Related Health Problems 10th Revision (ICD-10); for lung cancer, this referred to ICD-10: C34.0 to C34.9, but the data do permit to differentiate neither by histological type of cancer nor by tumour size.

Mortality was recorded with date of death as this terminates insurance membership. Due to German data privacy protection laws, only general mortality was recorded.

Income was available on the basis of individual wages as they are the basis for calculating insurance premiums. In order to make income data comparable over time, incomes were classified according to nationwide annual averages as published by the German Statistical Office. Women and men were classified into one of seven groups based on their pre-tax annual income $(>100 \%$ of national mean wage, $>80 \%-100 \%$ of national mean wage, $>60 \%-$ $80 \%$ of national mean wage, $>40 \%-60 \%$ of national mean wage, $>20 \%-40 \%$ of national mean wage, $<20$ of national mean wage, unclassified). The group of individuals with missing data on indicators of socioeconomic position is mainly made up out of family members without occupation, individuals who are on unemployment benefits or in training and education without receiving a regular salary. This group also includes self-employed individuals whose exact incomes are not reported to the health insurance. Thus, their mean age is lower than in the whole insurance population. ${ }^{26}$

Occupational position was classified according to a system of occupations as proposed by Blossfeld. ${ }^{27}$ Originally the classification contains 12 categories of occupations that are homogeneous with respect to education and vocational training and occupational activities (agricultural occupations, unskilled manual occupations, skilled manual occupations, technicians, engineers, unskilled services, skilled services, semi-professions, professions, unskilled commercial and administrational occupations, skilled commercial and administrational occupations, managers). For the following analyses, they were reduced to four: unskilled (eg, unskilled service personal), skilled (eg, skilled manual occupations like glassblowers), specialists (eg, semi-professions like nurses) and highly qualified positions (eg, professions like university professors) ${ }^{26}$ For falling into the 'highly qualified' group, a person usually needed a university degree, and the occupation included management tasks.

\section{Statistical analyses}

In the first line of analysis, it was examined whether incident cancer and non-cancer cases are differing with respect to SES. Employed insured were classified by occupational position and income, but for retired women and men, only income was available. Due to the unavailability of SES classifications, only employed and retired insured were considered. Thus, in the first line of analysis, we analysed whether incident lung cancer cases differed by SES via Cox regression analysis.

In the second line of analysis, only lung cancer cases were included. It was examined whether deaths (case fatalities) were differing by socioeconomic position. As above, separate analyses were performed for employed and retired insured. Thus, in the second line of analysis we analysed whether all-cause mortality of people with lung cancer differed by SES via Cox regression analysis.

In the third line of analysis, a time limit will be introduced to set a common condition for all socioeconomic groups. Case fatality rates will be analysed for a time period of 18 months after primary treatment of lung cancer. This will include all death cases up to this date, all other cases will be censorised. This requires the application of some restrictions on the data. In order to determine time periods correctly, incident and prevalent cases had to be separated. To exclude prevalent cases, a preobservation period of 1 year had to be introduced for all insured, thus leading to a reduction of cases. Then an observation period of 18 months was applied. According to national data, $40 \%$ of all lung cancer cases are expected to survive after this time period. ${ }^{1}$ This analysis constitutes a sensitivity analysis and enables judgements about the robustness of our analyses. Thus, in the third line of analysis, we analysed whether mortality in lung cancer cases differed by SES via Cox regression analysis with a maximum follow-up observation period of 18 months.

For the three lines of analyses, proportional hazards regression was applied. ${ }^{28}$ The Cox model estimates HRs for an endpoint to occur in different groups by setting one as point of reference. By estimating HRs, lengths of observation periods are taken into account what in our data is necessary due to censorisations and different lengths of insurance periods. All Cox regression analyses were controlled for age and stratified by gender and employment status. All estimations were performed by means of STATA V.15MP. ${ }^{29}$

\section{Patient and public involvement}

No patient involvement. It was not appropriate or possible to involve patients or the public in the design, or conduct, or reporting or dissemination plans of our research.

\section{RESULTS}

The basic distributions of the relevant variables are displayed in tables 1 and 2 . The total sum of person years covered with our dataset is 24744814 .

In table 3, HRs for lung cancer by group of insured are displayed. It has to be emphasised that controlling for age could only be incompletely successful as the retired insured were differing from the other groups mainly by their age structure. Below a certain age, only a very small fraction of all insured was falling into the group of retired insured. Except the heterogeneous unclassified group, all others had higher HRs than employed women and men. 


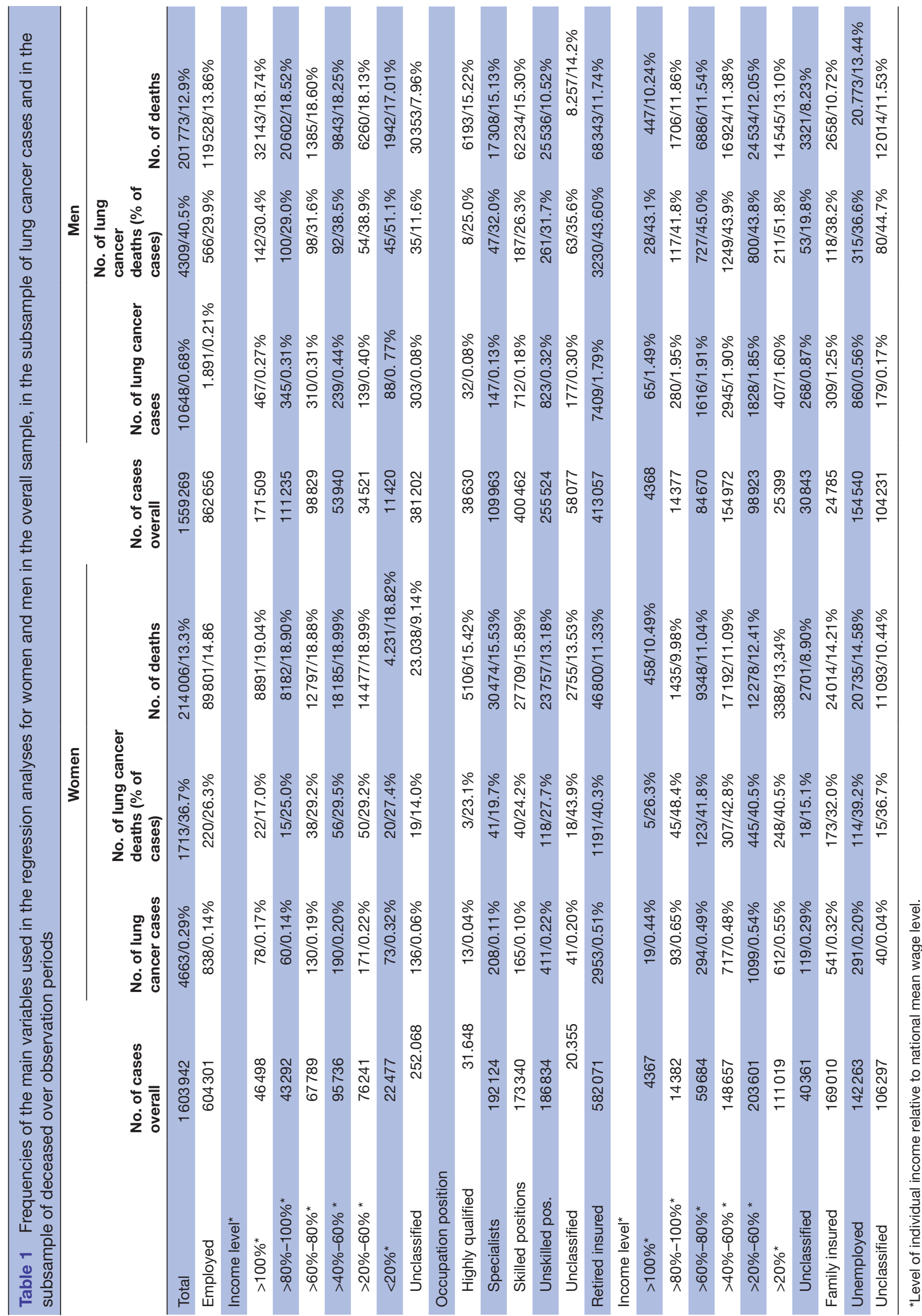


Table 2 Mean age at occurrence of lung cancer and mean age at death for patients with lung cancer

\begin{tabular}{lllll}
\hline & \multicolumn{2}{c}{ Women } & & \multicolumn{2}{c}{ Men } \\
\cline { 2 - 3 } \cline { 5 - 5 } & Age at occurrence, M (SD) & Age at death, M (SD) & Age at occurrence, M (SD) Age at death, M (SD) \\
\hline Employed & $55.1 / 7.0$ & $55.3 / 6.5$ & $56.9 / 6.9$ & $57.5 / 7.1$ \\
Retired & $71.0 / 8.4$ & $72.5 / 8.6$ & $71.2 / 7.7$ & $72.1 / 8.2$ \\
Unemployed & $56.9 / 8.7$ & $57.5 / 8.2$ & $57.3 / 7.6$ & $58.0 / 7.5$ \\
Family insured & $58.7 / 9.1$ & $60.5 / 9.7$ & $62.0 / 8.8$ & $62.9 / 8.9$ \\
Unclassified & $56.3 / 12.8$ & $60.7 / 9.7$ & $65.3 / 11.6$ & $65.9 / 11.6$ \\
\hline
\end{tabular}

In particular, the high HR among unemployed will have to be considered.

In the following analyses, only employed and retired insured were included. Table 4 shows the findings for incident or prevalent cases of lung cancer for employed and retired women and men.

In women, social differences were found only in the employed group. For the case of income, a gradient emerged for income, but due to large confidence boundaries, it was statistically significant only for the lowest income group. In contrast, a marked gradient emerged for occupation with a HR of 2.52 for the unskilled group. In retired women, income effects were completely absent. The rank order correlation between the two indicators was $r=0.32$.

In employed men, marked social differences were found for income as well as for occupation, although the rank order correlation was only $r=0.18$. Both indicators had independent effects on the disease outcome. This was reproduced in retired men where the effects were again substantial and statistically significant from the group with incomes below $40 \%$ of the national level. No interpretable effects emerged in the unclassified group.

Table 5 presents the findings for deaths. In men and in women, irrespective of whether employed or retired, social gradients were absent. Only in employed men earning less than $20 \%$ of the national average the HR was marginally significant. These general results were supported when conducting the analyses for 18 months of survival with death as endpoint (online supplementary appendix table A1).

\section{DISCUSSION}

We investigated whether there were social inequalities in the occurrence and mortality of lung cancer. Regarding the occurrence of lung cancer, social inequalities emerged for income as well as for occupational position in men and women, although in employed women, effects were only statistically significant in the lowest income group. In retired insured, social differences emerged only in men. This result is in line with previous studies. Multiple previous studies had found inequalities regarding smoking, occupation-related exposure to carcinogens and lung cancer. ${ }^{4-8}$ The main explanation for inequality in lung cancer incidence is that social inequalities tobacco consumption and occupation-related exposures may play a role. ${ }^{8}$ In Germany, the rates of smokers were decreasing from 1999 to 2013, but in men holding higher socioeconomic positions, this development took place at a faster pace than in lower positions. ${ }^{30}$ In women, smoking rates underwent a continuous decline in lower socioeconomic positions, while in higher socioeconomic positions, rates dropped from $24.2 \%$ to $15.7 \%$. Additionally, in a recent meta-analysis, the association between income and smoking rates had also been confirmed, particularly in countries with higher life expectancy. ${ }^{31}$ The authors explained this association with marketing strategies of tobacco companies and lower success of preventive measures in individuals with lower incomes. ${ }^{32}$ Thus, social inequalities regarding the occurrence of lung cancer emerged, which might largely be due to differential smoking rates and occupation-related exposures. This knowledge might also be useful to identify

Table 3 HRs for lung cancer by group of insured, estimated separately for women and men, controlled by age at occurrence

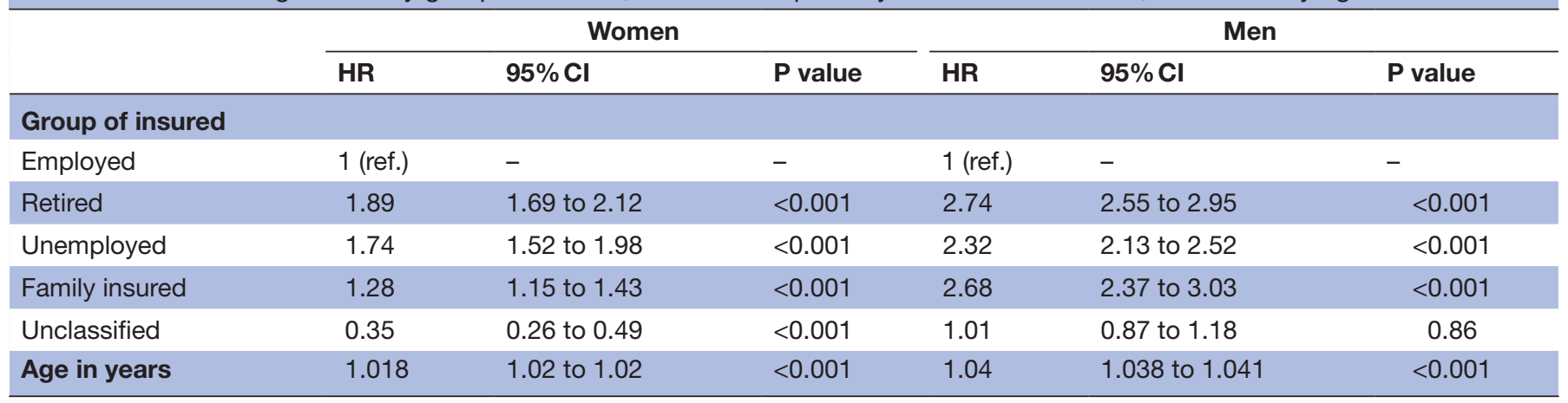


Table 4 HRs for having lung cancer, estimated separately for employed and retired female and male insured by controlling for age

\begin{tabular}{|c|c|c|c|}
\hline & \multicolumn{3}{|c|}{ Women, employed } \\
\hline & HR & $95 \% \mathrm{Cl}$ & $P$ value \\
\hline \multicolumn{4}{|l|}{ Income } \\
\hline $\begin{array}{l}>100 \% \text { of national mean } \\
\text { wage levels }\end{array}$ & 1 (ref.) & - & - \\
\hline $\begin{array}{l}>80 \%-100 \% \text { of national } \\
\text { mean wage levels }\end{array}$ & 0.72 & 0.51 to 1.01 & 0.06 \\
\hline $\begin{array}{l}>60 \%-80 \% \text { of national } \\
\text { mean wage levels }\end{array}$ & 0.98 & 0.74 to 1.30 & 0.88 \\
\hline $\begin{array}{l}>40 \%-60 \% \text { of national } \\
\text { mean wage levels }\end{array}$ & 1.02 & 0.78 to 1.34 & 0.87 \\
\hline $\begin{array}{l}>20 \%-40 \% \text { of national } \\
\text { mean wage levels }\end{array}$ & 1.24 & 0.94 to 1.63 & 0.14 \\
\hline $\begin{array}{l}<20 \text { of national mean wage } \\
\text { levels }\end{array}$ & 1.72 & 1.24 to 2.39 & $<0.01$ \\
\hline Unclassified & 1 & 0.75 to 1.34 & 0.97 \\
\hline \multicolumn{4}{|l|}{ Occupation } \\
\hline Highly qualified & 1 (ref.) & - & - \\
\hline Specialists & 2.28 & 1.30 to 4.0 & $<0.01$ \\
\hline Skilled positions & 2.08 & 1.18 to 3.67 & 0.01 \\
\hline Unskilled positions & 2.52 & 1.44 to 4.41 & $<0.01$ \\
\hline \multirow[t]{2}{*}{ Unclassified } & 1.46 & 0.77 to 2.78 & 0.25 \\
\hline & \multicolumn{3}{|c|}{ Women, retired } \\
\hline
\end{tabular}

\begin{tabular}{|c|c|c|c|}
\hline \multicolumn{4}{|l|}{ Income } \\
\hline $\begin{array}{l}>100 \% \text { of national mean } \\
\text { wage levels }\end{array}$ & 1 (ref.) & - & - \\
\hline $\begin{array}{l}>80 \%-100 \% \text { of national } \\
\text { mean wage levels }\end{array}$ & 1.5 & 0.92 to 2.47 & 0.1 \\
\hline $\begin{array}{l}>60 \%-80 \% \text { of national } \\
\text { mean wage levels }\end{array}$ & 1.19 & 0.75 to 1.89 & 0.47 \\
\hline $\begin{array}{l}>40 \%-60 \% \text { of national } \\
\text { mean wage levels }\end{array}$ & 1.17 & 0.74 to 1.84 & 0.51 \\
\hline $\begin{array}{l}>20 \%-40 \% \text { of national } \\
\text { mean wage levels }\end{array}$ & 1.09 & 0.69 to 1.71 & 0.74 \\
\hline $\begin{array}{l}<20 \text { of national mean wage } \\
\text { levels }\end{array}$ & 0.95 & 0.60 to 1.50 & 0.83 \\
\hline \multirow[t]{2}{*}{ Unclassified } & 0.73 & 0.45 to 1.19 & 0.2 \\
\hline & \multicolumn{3}{|c|}{ Men, employed } \\
\hline \multicolumn{4}{|l|}{ Income } \\
\hline $\begin{array}{l}>100 \% \text { of national mean } \\
\text { wage levels }\end{array}$ & 1 (ref.) & - & - \\
\hline $\begin{array}{l}>80 \%-100 \% \text { of national } \\
\text { mean wage levels }\end{array}$ & 1.15 & 1.00 to 1.32 & 0.05 \\
\hline $\begin{array}{l}>60 \%-80 \% \text { of national } \\
\text { mean wage levels }\end{array}$ & 1.45 & 1.26 to 1.68 & $<0.01$ \\
\hline $\begin{array}{l}>40 \%-60 \% \text { of national } \\
\text { mean wage levels }\end{array}$ & 2.09 & 1.79 to 2.45 & $<0.01$ \\
\hline $\begin{array}{l}>20 \%-40 \% \text { of national } \\
\text { mean wage levels }\end{array}$ & 2.22 & 1.82 to 2.70 & $<0.01$ \\
\hline
\end{tabular}

Continued
Table 4 Continued

\begin{tabular}{|c|c|c|c|}
\hline & \multicolumn{3}{|c|}{ Women, employed } \\
\hline & HR & $95 \% \mathrm{Cl}$ & $P$ value \\
\hline $\begin{array}{l}<20 \text { of national mean wage } \\
\text { levels }\end{array}$ & 2.35 & 1.84 to 3.00 & $<0.01$ \\
\hline Unclassified & 1.05 & 0.90 to 1.22 & 0.53 \\
\hline \multicolumn{4}{|l|}{ Occupation } \\
\hline Highly qualified & 1 (ref.) & - & - \\
\hline Specialists & 1.85 & 1.26 to 2.71 & $<0.01$ \\
\hline Skilled positions & 1.71 & 1.2 to 2.44 & $<0.01$ \\
\hline Unskilled positions & 2.76 & 1.93 to 3,94 & $<0.01$ \\
\hline \multirow[t]{2}{*}{ Unclassified } & 1.07 & 0.73 to 1.58 & 0.73 \\
\hline & \multicolumn{3}{|c|}{ Men, retired } \\
\hline \multicolumn{4}{|l|}{ Income } \\
\hline $\begin{array}{l}>100 \% \text { of national mean } \\
\text { wage levels }\end{array}$ & 1 (ref.) & - & - \\
\hline $\begin{array}{l}>80 \%-100 \% \text { of national } \\
\text { mean wage levels }\end{array}$ & 1.1 & 0.86 to 1.45 & 0.45 \\
\hline $\begin{array}{l}>60 \%-80 \% \text { of national } \\
\text { mean wage levels }\end{array}$ & 1.26 & 0.98 to 1.62 & 0.07 \\
\hline $\begin{array}{l}>40 \%-60 \% \text { of national } \\
\text { mean wage levels }\end{array}$ & 1.47 & 1.15 to 1.87 & $<0.01$ \\
\hline $\begin{array}{l}>20 \%-40 \% \text { of national } \\
\text { mean wage levels }\end{array}$ & 1.6 & 1.25 to 2.05 & $<0.01$ \\
\hline $\begin{array}{l}<20 \text { of national mean wage } \\
\text { levels }\end{array}$ & 1.52 & 1.17 to 1.98 & $<0.01$ \\
\hline Unclassified & 0.86 & 0.66 to 1.13 & 0.28 \\
\hline
\end{tabular}

vulnerable groups in lung cancer. Perhaps public health programmes could be developed and implemented that explicitly target groups with a lower SES in Germany.

Regarding the survival of lung cancer, we found no significant social inequalities. This result is not in line with some previous studies. Most previous studies found inequalities in survival of cancer, including in Germany. ${ }^{141820}$ This absence of social differences in survival may be explained by the universally applied cancer therapies (surgery, chemotherapy, radiation therapy and medications) being used under medical control without self-medication. This may leave only limited opportunity for non-compliance and thus ensures equal outcomes. Supporting this point, cancer therapies are also directed by guidelines, and under the conditions of the German healthcare system, financial barriers to lung cancer treatment are absent. Thus, no significant social inequalities regarding the survival of lung cancer resulted, which might be due to the equality in and universal appliance of lung cancer treatments in Germany. This may be different in countries where barriers to treatment do exist and where payments for treating the same disease are different. ${ }^{9}$ Another explanation for the absence of inequalities in survival from lung cancer might be that lung cancer is a very lethal disease. Perhaps, inequalities might have been observed in cancers with higher survival rates. Given the 
Table 5 HRs for deaths (case fatalities) after the occurrence lung cancer, estimated separately for employed and retired female and male insured patients by controlling for age for the whole observation period

\begin{tabular}{|c|c|c|c|}
\hline & \multicolumn{3}{|c|}{ Women, employed } \\
\hline & HR & $95 \% \mathrm{Cl}$ & $P$ value \\
\hline \multicolumn{4}{|l|}{ Income } \\
\hline $\begin{array}{l}>100 \% \text { of national mean } \\
\text { wage levels }\end{array}$ & 1 (ref.) & - & - \\
\hline $\begin{array}{l}>80 \%-100 \% \text { of national } \\
\text { mean wage levels }\end{array}$ & 0.94 & 0.48 to 1.83 & 0.85 \\
\hline $\begin{array}{l}>60 \%-80 \% \text { of national } \\
\text { mean wage levels }\end{array}$ & 1.05 & 0.62 to 1.80 & 0.86 \\
\hline $\begin{array}{l}>40 \%-60 \% \text { of national } \\
\text { mean wage levels }\end{array}$ & 0.98 & 0.59 to 1.64 & 0.95 \\
\hline $\begin{array}{l}>20 \%-40 \% \text { of national } \\
\text { mean wage levels }\end{array}$ & 0.91 & 0.53 to 1.55 & 0.72 \\
\hline $\begin{array}{l}<20 \text { of national mean wage } \\
\text { levels }\end{array}$ & 0.7 & 0.37 to 1.33 & 0.28 \\
\hline Unclassified & 0.36 & 0.19 to 0.68 & $<0.01$ \\
\hline \multicolumn{4}{|l|}{ Occupation } \\
\hline Highly qualified & 1 (ref.) & - & - \\
\hline Specialists & 0.92 & 0.28 to 3.04 & 0.89 \\
\hline Skilled positions & 1.2 & 0.36 to 3.99 & 0.76 \\
\hline Unskilled positions & 1.47 & 0.45 to 4.80 & 0.53 \\
\hline \multirow[t]{2}{*}{ Unclassified } & 3.63 & 1.02 to 12.99 & 0.05 \\
\hline & \multicolumn{3}{|c|}{ Women, retired } \\
\hline
\end{tabular}

\begin{tabular}{|c|c|c|c|}
\hline \multicolumn{4}{|l|}{ Income } \\
\hline $\begin{array}{l}>100 \% \text { of national mean } \\
\text { wage levels }\end{array}$ & 1 (ref.) & - & - \\
\hline $\begin{array}{l}>80 \%-100 \% \text { of national } \\
\text { mean wage levels }\end{array}$ & 1.95 & 0.77 to 4.93 & 0.16 \\
\hline $\begin{array}{l}>60 \%-80 \% \text { of national } \\
\text { mean wage levels }\end{array}$ & 1.72 & 0.70 to 4.22 & 0.24 \\
\hline $\begin{array}{l}>40 \%-60 \% \text { of national } \\
\text { mean wage levels }\end{array}$ & 1.75 & 0.72 to 4.24 & 0.22 \\
\hline $\begin{array}{l}>20 \%-40 \% \text { of national } \\
\text { mean wage levels }\end{array}$ & 1.74 & 0.72 to 4.21 & 0.22 \\
\hline $\begin{array}{l}<20 \text { of national mean wage } \\
\text { levels }\end{array}$ & 1.74 & 0.71 to 4.22 & 0.22 \\
\hline \multirow[t]{2}{*}{ Unclassified } & 0.63 & 0.23 to 1.72 & 0.37 \\
\hline & \multicolumn{3}{|c|}{ Men, employed } \\
\hline \multicolumn{4}{|l|}{ Income } \\
\hline $\begin{array}{l}>100 \% \text { of national mean } \\
\text { wage levels }\end{array}$ & 1 (ref.) & - & - \\
\hline $\begin{array}{l}>80 \%-100 \% \text { of national } \\
\text { mean wage levels }\end{array}$ & 0.97 & 0.75 to 1.26 & 0.82 \\
\hline $\begin{array}{l}>60 \%-80 \% \text { of national } \\
\text { mean wage levels }\end{array}$ & 1.03 & 0.79 to 1.35 & 0.8 \\
\hline $\begin{array}{l}>40 \%-60 \% \text { of national } \\
\text { mean wage levels }\end{array}$ & 1.26 & 0.96 to 1.65 & 0.09 \\
\hline $\begin{array}{l}>20 \%-40 \% \text { of national } \\
\text { mean wage levels }\end{array}$ & 1.21 & 0.88 to 1.68 & 0.25 \\
\hline
\end{tabular}

Continued
Table 5 Continued

\begin{tabular}{|c|c|c|c|}
\hline & \multicolumn{3}{|c|}{ Women, employed } \\
\hline & HR & $95 \% \mathrm{Cl}$ & $P$ value \\
\hline $\begin{array}{l}<20 \text { of national mean wage } \\
\text { levels }\end{array}$ & 1.46 & 1.01 to 2.09 & 0.05 \\
\hline Unclassified & 0.32 & 0.22 to 0.47 & $<0.01$ \\
\hline \multicolumn{4}{|l|}{ Occupation } \\
\hline Highly qualified & 1 (ref.) & - & - \\
\hline Specialists & 1.37 & 0.65 to 2.91 & 0.41 \\
\hline Skilled positions & 1.06 & 0.52 to 2.15 & 0.88 \\
\hline Unskilled positions & 1.43 & 0.70 to 2.91 & 0.33 \\
\hline \multirow[t]{2}{*}{ Unclassified } & 2.06 & 0.97 to 4.38 & 0.06 \\
\hline & \multicolumn{3}{|c|}{ Men, retired } \\
\hline \multicolumn{4}{|l|}{ Income } \\
\hline $\begin{array}{l}>100 \% \text { of national mean } \\
\text { wage levels }\end{array}$ & 1 (ref.) & - & - \\
\hline $\begin{array}{l}>80 \%-100 \% \text { of national } \\
\text { mean wage levels }\end{array}$ & 0.88 & 0.58 to 1.33 & 0.56 \\
\hline $\begin{array}{l}>60 \%-80 \% \text { of national } \\
\text { mean wage levels }\end{array}$ & 0.97 & 0.66 to 1.41 & 0.86 \\
\hline $\begin{array}{l}>40 \%-60 \% \text { of national } \\
\text { mean wage levels }\end{array}$ & 0.96 & 0.66 to 1.40 & 0.83 \\
\hline $\begin{array}{l}>20 \%-40 \% \text { of national } \\
\text { mean wage levels }\end{array}$ & 1.01 & 0.69 to 1.48 & 0.95 \\
\hline $\begin{array}{l}<20 \text { of national mean wage } \\
\text { levels }\end{array}$ & 1.22 & 0.82 to 1.82 & 0.32 \\
\hline Unclassified & 0.45 & 0.28 to 0.70 & $<0.01$ \\
\hline
\end{tabular}

divergence of our survival results from some studies in the literature, future studies should further examine case fatalities in cancer.

In an additional line of analysis, we examined differences in lung cancer among groups of insured. In our main analyses, we have included only the two groups of insured where SES indicators were available. Regarding the general differences between groups of insured, we found that unemployed had higher lung cancer risks than employed insured. This may at least be explained by the risk of unemployment increasing with decreasing qualification, ${ }^{33} 34$ thus individuals with lower qualification are likely to being more frequent in this group of insured. The higher lung cancer rate among family insured may also be explained by selection effects, that is, individuals with lung cancer may not return to work but decide to stay at home, particularly if partners are economically active, but there may be also other less specific reasons for this finding. Higher disease risks in family insured as compared with employed individuals were also reported for other types of disease..$^{35}$ Thus, we also found inequalities in the emergence lung cancer regarding insurance status, the reasons for which should be explored by future studies.

The current study has several strengths and limitation. Our data have the advantage of large case numbers, thus 
making it possible to study the occurrence of lung cancer as well as cancer deaths. The data have nevertheless also some shortcomings. Due to the nature of claims data, no information on smoking behaviour as the main risk factor are recorded. Also, comorbidities cannot be related to lung cancer as the structure of our data does not permit to establish causal relationships. The ICD-10 diagnoses are not differentiated by type of cancer or by disease stage. As can be seen from table 1, for some groups of insured, SES indicators were unavailable, and our data do not include privately insured women and men (14\% of the economically active part of the population). Our claims data are also skewed with respect to the social structure covered. ${ }^{25}$ Although the distributions of age and gender were corresponding to those of Lower Saxony and Germany as a whole, lower occupational groups were represented with higher frequencies. ${ }^{36}$ This does, however, not challenge our findings, but it may underestimate the social gradients reported. Furthermore, although the current study was able to use the objective individual income and occupational position to study inequality in lung cancer, there were some cases of unclassified incomes and occupational positions where it was not possible to assign an individual income and occupational position. Future studies should further investigate this subpopulation. Lastly, some of the literature has used other indicators of inequality such as income at the household level or the distinction between manual and non-manual workers. Future studies should replicate our results using these alternative operationalisations.

In conclusion, only few studies on health inequalities in terms of lung cancer in Germany were available. Thus, we examined social inequalities in the occurrence of lung cancer and the survival of patients with lung cancer, using a large claims dataset from a German statutory health insurance covering 2005-2016. Social gradients emerged regarding the occurrence of lung cancer, but not for the survival of patients with lung cancer, which might be explained by social differences in smoking behaviour, exposition to hazardous occupation-related substances and differences in preventive strategy use. The absence of social inequalities in death after lung cancer suggests equality in medical treatment of the disease. Future studies should examine whether our hypothesised causes of social inequalities in lung cancer can be empirically validated.

Contributors SS, JB and SG provided the idea for the manuscript. SS and SG prepared and analysed the data. All authors discussed the results. HG provided critical medical knowledge regarding lung cancer. All authors read and approved the final manuscript.

Funding This research was funded by the German Research Foundation (DFG; GE 1167/15-1) and the AOK Niedersachsen.

Competing interests None declared.

Patient consent for publication Not required.

Provenance and peer review Not commissioned; externally peer reviewed.

Data availability statement Data may be obtained from a third party and are not publicly available. The data that support the findings of this study are available from the AOK Niedersachsen but restrictions apply to the availability of these data, which were used under license for the current study, and so are not publicly available. Data are however available upon reasonable request and with permission of $\mathrm{Dr}$ Jona Stahmeyer of the AOK Niedersachsen.

Open access This is an open access article distributed in accordance with the Creative Commons Attribution Non Commercial (CC BY-NC 4.0) license, which permits others to distribute, remix, adapt, build upon this work non-commercially, and license their derivative works on different terms, provided the original work is properly cited, appropriate credit is given, any changes made indicated, and the use is non-commercial. See: http://creativecommons.org/licenses/by-nc/4.0/.

ORCID iD

Johannes Beller http://orcid.org/0000-0002-3041-9895

\section{REFERENCES}

1 RKI RKI. Krebs in Deutschland 2013/2014 [Cancer in Germany 2013/2014]. Berlin: Robert Koch Institut, 2017.

2 Zeiher J, Finger JD, Kuntz B, et al. Zeitliche trends beim rauchverhalten erwachsener in deutschland [trends in smoking among adults in Germany. evidence from seven population-based health surveys from 1991-2015]. Bundesgesundheitsblatt Gesundheitsforschung - Gesundheitsschutz 2018;61:1365-76.

3 Mackenbach JP, Huisman M, Andersen O, et al. Inequalities in lung cancer mortality by the educational level in 10 European populations. Eur J Cancer 2004;40:126-35.

4 Huisman M, Kunst AE, Mackenbach JP. Educational inequalities in smoking among men and women aged 16 years and older in 11 European countries. Tob Control 2005;14:106-13.

5 Hill S, Amos A, Clifford D, et al. Impact of tobacco control interventions on socioeconomic inequalities in smoking: review of the evidence. Tob Control 2014;23:e89-97.

6 Nawrot TS, Martens DS, Hara A, et al. Association of total cancer and lung cancer with environmental exposure to cadmium: the metaanalytical evidence. Cancer Causes Control 2015;26:1281-8.

7 Boffetta P. Epidemiology of environmental and occupational cancer. Oncogene 2004;23:6392.

8 Welch LS, Dement JM, Cranford K, et al. Early detection of lung cancer in a population at high risk due to occupation and smoking. Occup Environ Med 2019;76:137-42.

9 Bradley CJ, Given CW, Roberts C. Disparities in cancer diagnosis and survival. Cancer 2001;91:178-88.

10 Geyer S. Social inequalities in the incidence and case fatality of cancers of the lung, the stomach, the bowels, and the breast. Cancer Causes Control 2008;19:965-74.

11 Kuznetsov L, Maier W, Hunger M, et al. Regional deprivation in Bavaria, Germany: linking a new deprivation score with registry data for lung and colorectal cancer. Int J Public Health 2012;57:827-35.

12 Kuznetsov L, Maier W, Hunger M, et al. Associations between regional socioeconomic deprivation and cancer risk: analysis of population-based cancer registry data from Bavaria, Germany. Prev Med 2011;53:328-30.

13 Hoebel J, Kroll LE, Fiebig J, et al. Socioeconomic inequalities in total and site-specific cancer incidence in Germany: a population-based registry study. Front Oncol 2018;8:402.

14 Dalton SO, Schüz J, Engholm G, et al. Social inequality in incidence of and survival from cancer in a population-based study in Denmark, 1994-2003: summary of findings. Eur J Cancer 2008;44:2074-85.

15 Hovanec J, Siemiatycki J, Conway DI, et al. Lung cancer and socioeconomic status in a pooled analysis of case-control studies. PLoS One 2018;13:e0192999.

16 Hein HO, Suadicani P, Gyntelberg F. Lung cancer risk and social class. the Copenhagen male study--17-year follow up. Dan Med Bull 1992;39:173-6.

17 Mackillop WJ, Zhang-Salomons J, Boyd CJ, et al. Associations between community income and cancer incidence in Canada and the United States. Cancer 2000;89:901-12.

18 Dalton SO, Steding-Jessen M, Jakobsen E, et al. Socioeconomic position and survival after lung cancer: influence of stage, treatment and comorbidity among Danish patients with lung cancer diagnosed in 2004-2010. Acta Oncol 2015;54:797-804.

19 Schrijvers CT, Coebergh JW, van der Heijden LH, et al. Socioeconomic variation in cancer survival in the southeastern Netherlands, 1980-1989. Cancer 1995;75:2946-53.

20 Jansen L, Eberle A, Emrich K, et al. Socioeconomic deprivation and cancer survival in Germany: an ecological analysis in 200 districts in Germany. Int J Cancer 2014;134:2951-60. 
21 Rachet B, Ellis L, Maringe C, et al. Socioeconomic inequalities in cancer survival in England after the NHS cancer plan. Br J Cancer 2010;103:446-53.

22 Forrest LF, Adams J, Rubin G, et al. The role of receipt and timeliness of treatment in socioeconomic inequalities in lung cancer survival: population-based, data-linkage study. Thorax 2015;70:138-45.

23 Mitra D, Shaw A, Tjepkema M, et al. Social determinants of lung cancer incidence in Canada: a 13-year prospective study. Health Rep 2015;26:12-20.

24 Geyer S, Eberhard S, Schmidt BMW, et al. Morbidity compression in myocardial infarction 2006 to 2015 in terms of changing rates and age at occurrence: a longitudinal study using claims data from Germany. PLoS One 2018;13:e0202631.

25 Hoffmann F, Koller D, Regionen V. Verschiedene versichertenpopulationen? soziodemografische und gesundheitsbezogene unterschiede zwischen krankenkassen [different regions, differently insured populations? sociodemographic and health-related differences between insurance funds]. Gesundheitswesen 2017;79:e1-9.

26 Epping J, Muschik D, Geyer S. Social inequalities in the utilization of outpatient psychotherapy: analyses of registry data from German statutory health insurance. Int J Equity Health 2017;16:147.

27 Blossfeld $\mathrm{H}$. Bildungsexpansion und berufschancen: empirische analysen zur lage der berufsanfänger in der bundesrepublik. Frankfurt: Campus, 1985.

28 Cleves M, Gould W, Gutierrez RG, et al. An introduction to survival analysis using STATA. 3 edn. College Station, CA: Stata Press, 2010.

29 S C. Stata statistical software: release 15. College Station, TX: Stata Corporation, 2017.
30 Kuntz B, Kroll LE, Hoebel J, et al. Zeitliche entwicklung berufsgruppenspezifischer unterschiede im rauchverhalten von erwerbstätigen männern und frauen in deutschland. Bundesgesundheitsblatt Gesundheitsforschung Gesundheitsschutz 2018;61:1388-98.

31 Casetta B, Videla AJ, Bardach A, Soto N, et al. Association between cigarette smoking prevalence and income level: a systematic review and meta-analysis. Nicotine Tob Res 2017;19:1401-7.

32 Thomas S, Fayter D, Misso K, et al. Population tobacco control interventions and their effects on social inequalities in smoking: systematic review. Tob Control 2008;17:230-7.

33 OECD. OECD employment outlook. Paris: OECD Publishing, 2018.

34 OECD. Education at a glance 2018: OECD indicators. Paris: OECD Publishing, 2018.

35 Muschik D, Jaunzeme J, Geyer S. Can spouses' socio-economic information be used to determine the risk of type 2 diabetes in their partners? examining the consequences of a commonly used practice in studies on social inequalities in health. Int $J$ Public Health 2015;60:953-60.

36 Jaunzeme J, Eberhard S, Geyer S. Wie „repräsentativ" sind GKVDaten? demografische und soziale unterschiede und Ähnlichkeiten zwischen einer GKV-versichertenpopulation, der bevölkerung niedersachsens sowie der bundesrepublik am beispiel der AOK niedersachsen [how "representative" are data from statutory health insurances? demographic and social differences and similarities between a statutory health insurance population, the population of Lower Saxony and the Federal Republic of Germany at the example of the AOK Niedersachsen]. Bundesgesundheitsblatt 2013:56:447-54. 